\title{
Human stem cell-derived hepatocytes: breakthrough of an expedient tool for preclinical assessment of drug-induced liver injury?
}

\author{
Robim M. Rodrigues $\cdot$ Joery De Kock
}

Received: 23 December 2013 / Accepted: 14 January 2014 / Published online: 22 January 2014

(C) Springer-Verlag Berlin Heidelberg 2014

Detection of drug toxicity, often occurring late during the drug development process, is of major concern for the pharmaceutical industry and jeopardizes the potential marketing of new chemical entities (Pammolli et al. 2011; Goldkind and Laine 2006). In addition, one of the leading causes of post-marketing withdrawal of pharmaceuticals is drug-induced liver injury (DILI) (Russmann et al. 2009), suggesting that the currently used in vitro and in vivo preclinical models for assessing liver toxicity are not effective enough (Pammolli et al. 2011; Godoy et al. 2013; Olson et al. 2000). In line with recent regulatory developments in Europe for chemicals (EU 2006) and cosmetics (EU 2009), global consensus is growing to introduce, whenever possible, physiologically relevant alternative methods to animal testing, also in the pharmaceutical industry (Bouvier d'Yvoire et al. 2012). Current in vitro approaches for hepatotoxicity screening are mainly based on primary cells of different species, including man, or human hepatomaderived cell lines.

Primary human hepatocyte cultures represent the gold standard, but their use is hampered by their low availability and their inability to proliferate in culture (Fraczek et al. 2013). Due to intensive transplantation programs, hepatocytes can be seldom isolated from healthy human livers. Instead, they are obtained from patients suffering from severe liver injuries or coping with a multidrug regimen and therefore often display poor cell quality (Guguen-Guillouzo and Guillouzo 2010). Due to their scarcity, primary

R. M. Rodrigues · J. De Kock $(\bowtie)$

Department of In Vitro Toxicology and Dermato-Cosmetology, Center for Pharmaceutical Research, Vrije Universiteit Brussel, Laarbeeklaan 103, 1090 Brussels, Belgium

e-mail: jdekock@vub.ac.be human hepatocytes are also prohibitively expensive for high-throughput screening purposes.

Problems are also encountered when human hepatic cell lines are used, as these cells are mostly derived from liver cancer patients and do not adequately represent the normal population diversity (Guguen-Guillouzo and Guillouzo 2010). Consequently, innovative approaches to predict adverse liver responses in humans are urgently needed.

New developments coming from the rapidly advancing human stem cell research field are in the pipeline (McGivern and Ebert 2013). In fact, due to the biological flexibility of stem cells, biologists and toxicologists strongly believe that once the in vivo mechanisms driving cell differentiation and dedifferentiation are fully understood, stem cells can be modulated à la carte. As a consequence, these cells will obtain the appropriate functionalities that are required for evaluating a particular toxicological mode of action (MoA). As such, stem cells could represent a valuable "fit for purpose" tool in the unraveling of the MoA of a chemical substance at the molecular level.

Integration of stem cells in an in vitro setting to screen for toxicity could significantly increase the predictive capacity of the testing platform. Indeed, starting from embryonic and postnatal stem cells, functional hepatocyte-like cells can be generated that possess the required machinery to predict hepatotoxicity and provide valuable human-based toxicological information (Baxter et al. 2010; Snykers et al. 2009; Sullivan et al. 2010).

As an immediate consequence of the enormous advancement of "omics" technology during the last decade, an overwhelming amount of biologically relevant information can be generated and thanks to the availability of appropriate computational tools, the obtained data can be relatively easy and quickly interpreted. The first reports on accurate prediction of hepatotoxicity in response to specific 
pharmaceutical compounds using a combination of human stem cell-derived hepatocyte-like cells and omics technology are now a fact (Rodrigues et al. 2013; Medine et al. 2013). Toxic responses equivalent to those observed in primary human hepatocytes have been reported. These findings represent a major breakthrough in the field and provide an unambiguous proof-of-concept that human stem cell-derived hepatocytes have a high potential to improve the preclinical prediction of DILI. In the near future, stem cell-based in vitro assays might contribute to the development of an adverse outcome pathway (AOP) for a specific liver disease (Vinken et al. 2013).

\section{References}

Baxter MA, Rowe C, Alder J, Harrison S, Hanley KP, Park BK, Kitteringham NR, Goldring CE, Hanley NA (2010) Generating hepatic cell lineages from pluripotent stem cells for drug toxicity screening. Stem Cell Res 5:4-22. doi:10.1016/j.scr.2010.02.002

Bouvier d'Yvoire M, Bremer S, Casati S, Ceridono M, Coecke $\mathrm{S}$, Corvi R, Eskes C, Gribaldo L, Griesinger C, Knaut H, Linge JP, Roi A, Zuang V (2012) ECVAM and new technologies for toxicity testing. Adv Exp Med Biol 745:154-180. doi:10.1007/978-1-4614-3055-1_10

EU (2006) Regulation (EC) No 1907/2006 of the European Parliament and of the Council of 18 December concerning the Registration, Evaluation, Authorisation and Restriction of Chemicals (REACH), establishing a European Chemicals Agency, amending Directive/45/EC and repealing Council Regulation (EEC) No 793/93 and Commission Regulation (EC) No 1488/94 as well as Council Directive 76/769/EEC and Commission Directives 91/155/EEC, 93/67/EEC, 93/105/EC and 200/21/EC. Off J Eur Union 396:849-856

EU (2009) Regulation (EC) No 1223/2009 of the European Parliament and of the Council of 30 November 2009 on cosmetic products (recast). Off J Eur Union 342:59-209

Fraczek J, Bolleyn J, Vanhaecke T, Rogiers V, Vinken M (2013) Primary hepatocyte cultures for pharmaco-toxicological studies: at the busy crossroad of various anti-dedifferentiation strategies. Arch Toxicol 87:577-610. doi:10.1007/s00204-012-0983-3

Godoy P, Hewitt NJ, Albrecht U, Andersen ME, Ansari N, Bhattacharya S, Bode JG, Bolleyn J, Borner C, Böttger J, Braeuning A, Budinsky RA, Burkhardt B, Cameron NR, Camussi $\mathrm{G}$ et al (2013) Recent advances in 2D and 3D in vitro systems using primary hepatocytes, alternative hepatocyte sources and non-parenchymal liver cells and their use in investigating mechanisms of hepatotoxicity, cell signaling and ADME. Arch Toxicol 87:1315-1530. doi:10.1007/s00204-013-1078-5

Goldkind L, Laine L (2006) A systematic review of NSAIDs withdrawn from the market due to hepatotoxicity: lessons learned from the bromfenac experience. Pharmacoepidemiol Drug Saf 15:213-220. doi:10.1002/pds. 1207

Guguen-Guillouzo C, Guillouzo A (2010) General review on in vitro hepatocyte models and their applications. Methods Mol Biol 640:1-40. doi:10.1007/978-1-60761-688-7_1

McGivern JV, Ebert AD (2013) Exploiting pluripotent stem cell technology for drug discovery, screening, safety, and toxicology assessments. Adv Drug Deliv Rev. doi:10.1016/j.addr.2013.11.012

Medine CN, Lucendo-Villarin B, Storck C, Wang F, Szkolnicka D, Khan F, Pernagallo S, Black JR, Marriage HM, Ross JA, Bradley M, Iredale JP, Flint O, Hay DC (2013) Developing high-fidelity hepatotoxicity models from pluripotent stem cells. Stem Cell Transl Med 2:505-509. doi:10.5966/sctm.2012-0138

Olson H, Betton G, Robinson D, Thomas K, Monro A, Kolaja G, Lilly P, Sanders J, Sipes G, Bracken W, Dorato M, Van Deun K, Smith P, Berger B, Heller A et al (2000) Concordance of the toxicity of pharmaceuticals in humans and in animals. Regul Toxicol Pharmacol 32:56-67. doi:10.1006/rtph2000.1399

Pammolli F, Magazzini L, Riccaboni M (2011) The productivity crisis in pharmaceutical R\&D. Nat Rev Drug Discov 10:428-438. doi: $10.1038 / \mathrm{nrd} 3405$

Rodrigues RM, De Kock J, Branson S, Vinken M, Meganathan K, Chaudhari U, Sachinidis A, Govaere O, Roskams T, De Boe V, Vanhaecke T, Rogiers V (2013) Human skin-derived stem cells as a novel cell source for in vitro hepatotoxicity screening of pharmaceuticals. Stem Cells Dev. doi:10.1089/scd.2013.0157

Russmann S, Kullak-Ublick GA, Grattagliano I (2009) Current concepts of mechanisms in drug-induced hepatotoxicity. Curr Med Chem 16:3041-3053

Snykers S, De Kock J, Rogiers V, Vanhaecke T (2009) In vitro differentiation of embryonic and adult stem cells into hepatocytes: state of the art. Stem Cells 27:577-605. doi:10.1634/stemce 1ls.2008-0963

Sullivan GJ, Hay DC, Park IH, Fletcher J, Hannoun Z, Payne CM, Dalgetty D, Black JR, Ross JA, Samuel K, Wang G, Daley GQ, Lee JH, Church GM, Forbes SJ et al (2010) Generation of functional human hepatic endoderm from human induced pluripotent stem cells. Hepatology 51:329-335. doi:10.1002/hep.23335

Vinken M, Landesmann B, Goumenou M, Vinken S, Shah I, Jaeschke H, Willett C, Whelan M, Rogiers V (2013) Development of an adverse outcome pathway from drug-mediated bile salt export pump inhibition to cholestatic liver injury. Toxicol Sci 36(1):97106. doi:10.1093/toxsci/kft177 